\title{
MENINGKATKAN AKTIVITAS DAN KREATIFITAS SISWA MELALUI COLLABORATIVE LEARNING
}

\author{
Widya Roshandi \\ Srinarti Koestiani \\ SMAN 6 Kediri \\ sands_muscle@yahoo.com
}

\begin{abstract}
This research aims to enhance the activity and creativity of accounting students through a collaborative learning model for the eleventh grade students of Social Studies 5 at SMAN 6 Kediri. This research is a Classroom Action Research. The object of the study is accounting learning process in classroom while the subject of the study is all students in the classroom. This study was conducted in two cycles, the first cycle consists of three meetings and the second cycle consists of two meetings. Before giving thetreatment (using collaborative learning), students were given pre-treatment test. At the end of each cycle, there was a post-test. The findings show that collaborative learning within accounting teaching and learning run well and increases the activity and creativity of students.
\end{abstract}

Keywords: Collaborative Learning, Activity, Creativity

Abstrak: Penelitian ini bertujuan untuk meningkatkan aktivitas dan kreatifitas siswa dalam pembelajaran akuntansi dengan model collaborative learning pada siswa kelas XI IPS 5 SMAN 6 Kediri. Penelitian ini merupakan Penelitian Tindakan Kelas (PTK). Objek penelitian adalah proses pembelajaran akuntasnsi pada kelas XI IPS 5 SMAN 6 Kediri dan subjek dari penelitian adalah semua siswa yang ada di kelas tersebut. Penelitian ini dilaksanakan dalam dua siklus, yakni siklus I terdiri dari tiga kali pertemuan dan siklus II terdiri dari dua kali pertemuan. Sebelum memberikan tindakan (menggunakan collaborative learning), siswa diberi tes pratindakan. Pada akhir tiap siklus, diberikan posttest. Temuan yang didapatkan adalah bahwa pembelajaran akuntansi dengan collaborative learning dapat berjalan dengan baik dan mampu meningkatkan aktivitas dan kreatifitas siswa.

Kata kunci :Collaborative Learning, Aktivitas, Kreatifitas

\section{Pendahuluan}

Dari hasil pengamatan pengajaran akuntansi di SMAN 6 Kediri ditemukan beberapa kelemahan diantaranya adalah kurangnya aktivitas dan kreatifitas siswa yang dapat dilihat dari kurangnya keinginan bertanya atau menjawab pertanyaan dari guru, siswa hanya datang duduk diam. Jika diberi pertanyaan oleh guru, siswa hanya berbisik - bisik dengan temanya tanpa ada kemauan 
menjawab, siswa tidak mau membaca literatur lainya yang memudahkan mereka mengerjakan tugas. Hal tersebut menyebabkan nilai rata-rata siswa kurang maksimal yaitu 65 atau 10 angka dibawah KKM.Selain dari faktor siswa dalam proses pembelajaran, peran guru juga sangat penting. Pada awalnya cara guru mengajar di SMAN 6 Kediri khususnya guru akuntansi rata-rata mengajar dengan metode ceramah dan mengharapkan siswa duduk, diam, mencatat dan hafal. Pola penyampaian guru yang monoton membuat siswa malas, bosan dan tidak bisa berkreasi sesuai keinginan mereka.

Siswa SMAN 6 Kediri memang kurang dalam kemampuan akademik namun mereka unggul di aspek psikomotor sehingga ketika cara penyampaian pelajaran bersifat monoton, siswa cenderung tidur di kelas. Untuk mengatasi hal tersebut maka harus dibuat sebuah pembelajaran yang menekankan pada aspek psikomotor agar siswa lebih bersemangat belajar.Salah salah satu alternatif untuk mengatasi permasalahan di atas adalah penggunaan strategi mengajar, pemilihan strategi pembelajaran yang menarik dan dapat memicu siswa untuk ikut serta secara aktif dan kreatif dalam kegiatan belajar mengajar.

Menurut Sanjaya (2008) aktivitas belajar itu tidak hanya berupa aktivitas fisik semata, akan tetapi juga melibatkan aktivitas mental dan emosional. Untuk aktivitas fisik, guru dapat dengan jelas mengamati pada tiap siswa, akan tetapi untuk aktivitas mental dan emosional,tidak dapat diamati secara langsung oleh guru.

Guru hanya dapat mengamati aktivitas belajar melalui gejala yang nampak dari adanya aktivitas mental dan emosional siswa tersebut, seperti bertanya, menanggapi, menjawab pertanyaan guru, diskusi, memecahkan permasalahan, melaporkan hasil kerja, membuat rangkuman, dan sebagainya. Aktivitas-aktivitas tersebut terjadi karena adanya interaksi individu dengan lingkungannya

Aktivitas belajar banyak sekali macamnya, sehingga para ahli mengadakan klasifikasi. Hamalik (2001) mengklasifikasikan aktivitas belajar atas delapan kelompok, yaitu: (1) Kegiatan-kegiatan Visual: Membaca, melihat gambar-gambar, mengamati eksperimen, demonstrasi, pameran, dan mengamati orang lain bekerja dan bermain; (2) Kegiatan-kegiatan Lisan (oral): Mengemukakan suatu fakta atau prinsip, menghubungkan suatu kejadian, mengajukan pertanyaan, memberi saran, mengemukakan pendapat, wawancara, diskusi dan interupsi; (3) Kegiatan-kegiatan Mendengarkan: Mendengarkan penyajian bahan, 
mendengarkan percakapan atau diskusi kelompok, mendengarkan suatu permainan, mendengarkan radio; (4) Kegiatan-kegiatan Menulis: Menulis cerita, menulis laporan, memeriksa karangan, membuat rangkuman, mengerjakan tes dan mengisi angket; (5)Kegiatankegiatan Menggambar: Menggambar, membuat grafik, chart, diagram, peta dan pola; (6) Kegiatan-kegiatan Metrik: Melakukan percobaan, memilih alat-alat, melaksanakan pameran, membuat model, menyelenggarakan permainan, menari dan berkebun; (7) Kegiatan-kegiatan Mental: Merenung, mengingat, memecahkan masalah, menganalisis faktor-faktor, melihat hubungan-hubungan dan membuat keputusan; (8) Kegiatan-kegiatan Emosional: Minat, membedakan, berani, tenang dan lain-lain.

Menurut Sanjaya dalam Ari (2011), Pembelajaran Aktif (Active Learning) siswa dilihat dari proses pembelajaran yang meliputi: (1) Adanya keterlibatan siswa baik secara fisik, mental, emosional maupun intelektual dalam setiap proses pembelajaran. Hal ini dapat dilihat dari tingginya perhatian serta motivasi siswa untuk menyelesaikan setiap tugas yang diberikan sesuai dengan waktu yang telah ditentukan; (2) Siswa belajar secara langsung (Experimental Learning). Pengalaman nyata, seperti merasakan, meraba, mengoperasikan, melakukan sendiri, dan lain sebagainya bisa dilakukan dalam bentuk kerja sama dan interaksi dalam kelompok; (3) Adanya keinginan siswa untuk menciptakan iklim belajar yang kondusif; (4) Keterlibatan siswa dalam mencari dan memanfaatkan setiap sumber belajar yang tersedia yang dianggap relevan dengan tujuan pembelajaran; (4) Adanya keterlibatan siswa dalam melakukan prakarsa seperti menjawab dan mengajukan pertanyaan, berusaha memecahkan masalah yang diajukan atau yang timbul selama proses pembelajaran berlangsung; (5) Terjadinya interaksi yang multi arah, baik antara siswa dengan siswa atau antara guru dengan siswa. Interaksi ini juga ditandai dengan keterlibatan semua siswa secara merata, artinya pembelajaran atau proses tanya jawab tidak didominasi oleh siswa-siswa tertentu.

Secara alamiah perkembangan anak berbeda-beda, baik dalam bakat, minat, jasmani, kematangan emosi, kepribadian, keadaan jasmani, dan sosialnya. Selain itu, setiap anak memiliki kemampuan tak terbatas dalam belajar untuk dapat berfikir kereatif dan produktif. Kreativitas menurut kamus besar Bahasa Indonesia berasal dari kata dasar kreatif, yaitu memiliki kemampuan untuk menciptakan sesuatu. Menurut Munandar (2004), kreativitas adalah kemampuan untuk membuat kombinasi baru berdasarkan data, informasi atau unsur-unsur yang 
ada. Kreativitas juga diartikan dengan kemampuan yang berdasarkan data atau informasi yang menemukan banyak kemungkinan jawaban terhadap suatu masalah, dimana pendekatannya adalah pada kuantitas dan keragaman jawaban. Secara operasional, kreativitas dapat dirumuskan sebagai kemampuan yang mencerminkan kelancaran keluwesan (fleksibilitas), dan orisinalitas dalam berfikir, serta kemampuan untuk mengelaborasi (mengembangkan, memperkaya, memperinci) suatu gagasan. Salah satu konsep yang amat penting dalam bidang kreativitas adalah hubungan antara kreativitas dan aktualisasi diri.

Menurut Munandar (2004), seseorang dikatakan mengaktualisasikan dirinya apabila seseorang menggunakan semua bakat dan talentanya untuk menjadi apa yang ia mampu menjadi, mengaktualisasikan, atau mewujudkan potensinya. Aktualisasi diri merupakan karakteristik yang fundamental, suatu potensialitas yang ada pada semua manusia saat dilahirkan, akan tetapi sering hilang, terhambat atau terpendam dalam proses pembudayaan. Jadi, sumber dari kreativitas adalah kecenderungan untuk mengaktualisasi diri, mewujudkan potensi, dorongan untuk berkembang dan menjadi matang. Hamdani (2002) mengemukakan bahwa kreativitas dapat ditinjau dari (3) hal, yaitu: (1) Kreativitas adalah suatu kemampuan, yaitu kemampuan untuk membayangkan atau menciptakan sesuatu yang baru, kemampuan untuk membangun ide-ide baru dengan mengombinasikan, mengubah, menerapkan ulang ide-ide yang sudah ada; (2) Kreativitas adalah suatu sikap, yaitu kemauan untuk menerima perubahan dan pembaharuan, bermain dengan ide dan memiliki fleksibilitas dalam pandangan; (3) Kreativitas adalah suatu proses, yaitu proses bekerja keras dan terus menerus sedikit demi sedikit untuk membuat perubahan dan perbaikan terhadap pekerjaan yang dilakukan.

Kreativitas dapat diartikan sebagai kemampuan untuk berfikir tentang sesuatu dengan suatu cara yang baru dan tidak biasa serta menghasilkan penyelesaian yang unik terhadap berbagai persoalan. Dari beberapa defenisi oleh para ahli, dapat disimpulkan bahwa kreativitas adalah suatu kemampuan untuk menciptakan sesuatu yang baru yang berbeda dari sebelumnya, baik berupa gagasan atau karya nyata dengan menggabung-gabungkan unsur-unsur yang sudah ada sebelumnya. Hal baru disini adalah sesuatu yang belum diketahui olehnya, meskipun hal itu merupakan hal yang tidak asing lagi bagi orang lain, dan bukan hanya dari yang tidak menjadi ada, tetapi juga kombinasi baru dari sesuatu yang sudah ada. 
Susanto (2011) menyatakan bahwa pada umumnya kreativitas dirumuskan dalam beberapa istilah, yaitu :Pribadi (person), yaitu kreativitas mengacu kepada kemampuan yang merupakan ciri/karakteristik dari orang-orang kreatif. Maksudnya, kreativitas merupakan ungkapan unik dari seluruh pribadi sebagai hasil interaksi individu, perasaan, sikap, dan perilakunya; Proses (process), yaitu kreativitas merupakan proses yang mencerminkan kelancaran dalam berfikir; Pendorong (press), yaitu inisiatif seseorang yang tercermin melalui kemampuannya untuk melepaskan diri dari urutan pikiran yang biasa; dan Produk (product), yaitu kemampuan untuk menghasilkan sesuatu yang baru.

Pada penelitian ini peneliti ingin menerapkan Collaborative learning untuk meningkatkan aktifitas dan kreatifitas siswa. Dalam penerapan collaborative learning ini siswa diharapkan mampu mengembangkan kreativitas dalam menyelesaikan soal akuntansi serta lebih aktif dalam bekerja sama. Dalam model pembelajaran collaborative, siswa menegosiasikan usahanya sendiri. Guru hanya membimbing siswa dalam menemukan informasi sehingga siswa bisa lebih aktif dan kreatif dalam belajar. Tugas guru disini hanya mengarahkan bukan mengajarkan atau memberi jawaban atas kesulitan yang dialami siswa.

Dewasa ini model cooperative dan collaborative sering disamaartikan oleh para pendidik namun pada dasarnya kedua model ini berbeda. Cooperative adalah model pembelajaran berkelompok dengan penugasan secara kelompok. Dari sini dapat dilihat kelemahan dari pembelajaran cooperatif yaitu penilaian hanya berdasarkan tugas kelompok, sedangkan model pembelajaran collaborative adalah model pembelajaran di mana siswa dalam satu kelompok yang bervariasi tingkat kemampuanya bekerjasama dalam kelompok kecil untuk mencapai tujuan bersama.

Berbeda dengan pembelajaran cooperatif, model pembelajaran collaborative memberikan penilaian berdasarkan tugas individu dan kelompok sehingga terlihat antara siswa kurang pintar dengan siswa yang pintar. Selain itu, model pembelajaran collaborative dapat meningkatkan mengembangkan cara berpikir kritis dan rasional, meningkatkan persaingan sehat dalam kelompok serta meningkatkan aktivitas individu karena mereka memiliki tugas individu yang akan dipertanggungjawabkan pada kelompok.

Dalam model pembelajaran collaborative siswa menegosiasikan usahanya sendiri. Guru hanya membimbing siswa dalam menemukan informasi sehingga siswa bisa lebih aktif dan 
kreatif dalam belajar. Tugas guru disini hanya mengarahkan bukan mengajarkan atau memberi jawaban atas kesulitan yang dialami siswa. Pembelajaran dengan model collaborative lebih berorientasi pada proses sedangkan model cooperative lebih menekankan pada hasil.

Collaborative Learning berorientasi pada teori konstruktivisme yaitu Teori belajar konstruktivistik yang bermula dari gagasan Piaget dan Vigotsky (1989). Piaget dan Vigotsky berpendapat bahwa perubahan kognitif hanya terjadi jika konsepsi-konsepsi yang telah dipahami sebelumnya diolah melalui suatu proses ketidakseimbangan dalam upaya memahami informasiinformasi baru. Keduanya menekankan adanya hakekat sosial dari belajar. Aunurrahman (2009) menegaskan bahwa "konstruktivistik memberikan arah yang jelas bahwa kegiatan belajar merupakan kegiatan aktif dalam upaya menemukan pengetahuan, konsep, kesimpulan, bukan sekedar merupakan kegiatan mekanistik untuk mengumpulkan informasi atau fakta saja". Selanjutnya menurut Sanjaya (2008) "konstruktivistik adalah proses membangun atau menyusun pengetahuan baru dalam struktur kognitif siswa berdasarkan pengalaman. Guru bukanlah pemberi informasi, dan jawaban atas semua masalah yang terjadi di kelas”.

Menurut Aunurahman (2009), Pembelajaran kolaboratif menuntut adanya modifikasi tujuan pembelajaran dari yang semula sekedar penyampaian informasi menjadi konstruksi pengetahuan oleh individu melalui belajar kelompok. Dalam belajar kolaboratif, tidak ada perbedaan tugas untuk masing-masing individu, melainkan tugas itu milik bersama dan diselesaikan secara bersama tanpa membedakan percakapan belajar siswa.

Ada banyak macam pembelajaran kolaboratif yang pernah dikembangkan oleh para ahli maupun praktisi pendidikan. Diantaranya oleh para ahli Student Team Learning (Bennett, Howe, dan Truswell, 2002) ynag dilakukan di John Hopkins University menggunakan metode Learning Together, Teams Games Tournament, STAD dan Jigsaw. Pembelajaran tersebut diterapkan untuk meningkatkan aktivitas dan kreatifitas siswa. Aktivitas belajar adalah aktivitas yang bersifat fisik, maupun mental. Kedua aktivitas tersebut harus selalu terkait satu sama lain selama kegiatan belajar, dan harus ada keserasian diantara keduanya.

\section{METODE}

Penelitian ini adalah Penelitian Tindakan Kelas (PTK). Penelitian tindakan kelas merupakan suatu pencermatan terhadap kegiatan belajar berupa sebuah tindakan, yang sengaja 
dimunculkan dan terjadi dalam sebuah kelas secara bersama.Tindakan tersebut diberikan oleh guru atau dengan arahan dari guru yang dilakukan oleh siswa. Kesalahan umum yang terdapat dalam penelitian tindakan kelas adalah penonjolan tindakan yang dilakukan guru sendiri, misalnya guru memberikan tugas kelompok kepada siswa. Pada penelitian ini ditekankan pada tindakan yang dilakukan oleh peserta didik di bawah bimbingan dan arahan guru.

Dalam penelitian ini peneliti sebagai observer, perencana, pelaksana, pengumpul data, penganalisis data serta pelapor hasil penelitian. Peneliti mengamati langsung peristiwa yang terjadi di kelas saat dilakukan proses KBM. Peneliti dibantu lima orang mahasiswa yang berperan sebagai observer dan seorang guru mata pelajaran akuntansi yang berperan sebagai pelaksana kegiatan atau strategi belajar mengajar yang diharapkan mempermudah peneliti dalam mengamati aktivitas dan kreatifitas siswa.

Penelitian ini akan dilaksanakan di SMAN 6 Kediri pada semester genap tahun ajaran 2013/2014 di kelas XI IPS 5 dengan waktu 2 jam mata pelajaran. Penelitian dilaksanakan dalam 2 siklus. Subjek dalam penelitian ini adalah siswa kelas XI IPS 5 SMAN 6 Kediri yang siswanya berjumlah 29 siswa. Objek penelitian ini adalah aktivitas dan kreatifitas siswa kelas XI IPS SMAN 6 Kediri tahun pelajaran 2013/2014 pada kompetensi dasar siklus akuntansi perusahaan jasa. Jenis data yang digunakan dalam penelitian adalah data primer. Dalam penelitian ini, pemilihan informan menggunakan teknik purposive sampling .

Teknik pengumpulan data menggunakan observasi, dokumentasi, dan wawancara, sementara analisis data dilakukan secara kualitatif, meliputi reduksi data, paparan data dan penyimpulan, serta analisis secara kuantitatif digunakan untuk mempermudah dalam menganalisis peningkatan Aktivitas Belajar Siswa.

\section{Tabel 1. Indikator Aktivitas Belajar.}

\begin{tabular}{|c|l|c|c|c|c|}
\hline \multirow{2}{*}{ No } & \multicolumn{1}{|c|}{ Indikator } & \multicolumn{4}{|c|}{ Skor } \\
\cline { 4 - 6 } & & 1 & 2 & 3 & 4 \\
\hline 1 & Memperhatikan apa yang disampaikan guru & & & & \\
\hline 2 & Berani perform dan menyampaikan pendapat & & & & \\
\hline 3 & Berani bertanya saat menghadapi kesulitan & & & \\
\hline 4 & Bertanggung jawab terhadap tugas masing-masing & & & & \\
\hline
\end{tabular}




\begin{tabular}{|c|l|c|c|c|c|}
\hline 5 & Mencari refernsi lain selain buku & & & \\
\hline 6 & Semangat belajar & & & & \\
\hline 7 & Menyelesaikan tugas mandiri & & & & \\
\hline 8 & Menanggapi pendapat teman & & & \\
\hline Total & & & & \\
\hline
\end{tabular}

Meningkatnya Aktivitas Belajar siswa dapat dilihat dari meningkatnya persentase Aktivitas Belajar siswa dari pra penelitian ke pasca penelitian. Dalam penelitian ini, kriteria keberhasilan peningkatan Aktivitas Belajar siswa adalah minimal sebesar 75\% yang didasarkan pada ketercapaian masing-masing indikator Aktivitas Belajar siswa.

Tabel 2. Indikator Tingkat Kreatifitas Siswa.

\begin{tabular}{|c|l|c|c|c|c|}
\hline \multirow{2}{*}{ No } & \multicolumn{1}{|c|}{ Indikator } & \multicolumn{4}{|c|}{ Skor } \\
\cline { 3 - 6 } & & 1 & 2 & 3 & 4 \\
\hline 1 & Kelancaran Berpikir & & & & \\
\hline 2 & Berfikir Luwes & & & & \\
\hline 3 & Berpikir Original & & & & \\
\hline 4 & Bersifat Imajinatif & & & & \\
\hline 5 & Rasa ingin tahu & & & & \\
\hline 6 & Berani mengambil resiko & & & & \\
\hline & & & & & \\
\hline & Total & & & \\
\hline
\end{tabular}

Tabel 3. Pedoman Penilaian Tingkat Kreatifitas Siswa.

\begin{tabular}{|c|l|l|l|l|l|}
\hline No & Indikator & \multicolumn{1}{|c|}{ Skor 1 } & \multicolumn{1}{c|}{ Skor 2 } & Skor 3 & \multicolumn{1}{|c|}{ Skor 4 } \\
\hline 1 & $\begin{array}{l}\text { Kelancaran } \\
\text { Berpikir }\end{array}$ & $\begin{array}{l}\text { Sering } \\
\text { bertanya dan } \\
\text { menjawab } \\
\text { pertanyaan }\end{array}$ & $\begin{array}{l}\text { Punya banyak } \\
\text { ide dan mampu } \\
\text { mengungkapkan } \\
\text { dengan baik }\end{array}$ & $\begin{array}{l}\text { Menyelesai } \\
\text { kan tugas } \\
\text { dengan } \\
\text { cepat dan } \\
\text { tepat }\end{array}$ & $\begin{array}{l}\text { Cepat } \\
\text { mengerti dan } \\
\text { mengidentifi } \\
\text { kasi } \\
\text { kesalahan } \\
\text { pada objek }\end{array}$ \\
\hline 2 & $\begin{array}{l}\text { Berfikir } \\
\text { luwes }\end{array}$ & $\begin{array}{l}\text { Memiliki } \\
\text { interpretasi } \\
\text { yang berbeda } \\
\text { dengan yang } \\
\text { lain }\end{array}$ & $\begin{array}{l}\text { Memberi } \\
\text { pertimbangan } \\
\text { berbeda saat } \\
\text { diskusi }\end{array}$ & $\begin{array}{l}\text { Memiliki } \\
\text { sudut } \\
\text { pandang } \\
\text { yang } \\
\text { berbeda saat }\end{array}$ & $\begin{array}{l}\text { Mampu } \\
\text { mengubah } \\
\text { arah pikiran } \\
\text { secara } \\
\text { spontan }\end{array}$ \\
\hline
\end{tabular}




\begin{tabular}{|c|l|l|l|l|l|}
\hline 3 & $\begin{array}{l}\text { Berpikir } \\
\text { Original }\end{array}$ & $\begin{array}{l}\text { Memikirkan } \\
\text { cara baru } \\
\text { dalam } \\
\text { menyelesaiak } \\
\text { an masalah }\end{array}$ & $\begin{array}{l}\text { Menggunakan } \\
\text { cara berpikir } \\
\text { sendiri tanpa } \\
\text { terpengaruh } \\
\text { orang lain }\end{array}$ & $\begin{array}{l}\text { Memahami } \\
\text { dan } \\
\text { berusaha } \\
\text { menemukan } \\
\text { cara baru } \\
\text { dalam } \\
\text { penyelesaia } \\
\text { n masalah }\end{array}$ & $\begin{array}{l}\text { Senang } \\
\text { menganalisa } \\
\text { masalah dan } \\
\text { tidak terburu- } \\
\text { buru } \\
\text { menjawab }\end{array}$ \\
\hline 4 & $\begin{array}{l}\text { Bersifat } \\
\text { Imajinatif }\end{array}$ & $\begin{array}{l}\text { Cenderung } \\
\text { ikut suara } \\
\text { mayoritas }\end{array}$ & $\begin{array}{l}\text { Sering } \\
\text { memprediksi } \\
\text { suatu masalah }\end{array}$ & $\begin{array}{l}\text { Melihat hal- } \\
\text { hal baru } \\
\text { untuk } \\
\text { memecahka } \\
\text { n masalah }\end{array}$ & $\begin{array}{l}\text { Membuat } \\
\text { korelasi } \\
\text { antara } \\
\text { masalah } \\
\text { dengan } \\
\text { kejadian } \\
\text { relevan }\end{array}$ \\
\hline 5 & $\begin{array}{l}\text { Rasa ingin } \\
\text { tahu }\end{array}$ & $\begin{array}{l}\text { Hanya datang } \\
\text { duduk diam }\end{array}$ & $\begin{array}{l}\text { kritis terhadap } \\
\text { orang lain,peka } \\
\text { dan perasa }\end{array}$ & $\begin{array}{l}\text { Tidak } \\
\text { membutuhk } \\
\text { an dorongan } \\
\text { teman untuk } \\
\text { bertanya }\end{array}$ & $\begin{array}{l}\text { Cenderung } \\
\text { tertarik } \\
\text { kepada hal- } \\
\text { hal yang } \\
\text { kompleks }\end{array}$ \\
\hline 6 & $\begin{array}{l}\text { Berani } \\
\text { mengambil } \\
\text { resiko }\end{array}$ & $\begin{array}{l}\text { Berani } \\
\text { memperta } \\
\text { hankan } \\
\text { gagasan }\end{array}$ & $\begin{array}{l}\text { Mau mengakui } \\
\text { kesalahan- } \\
\text { kesalahan sendiri }\end{array}$ & $\begin{array}{l}\text { Mengemuka } \\
\text { kan } \\
\text { pendapat } \\
\text { meski } \\
\text { belum tentu } \\
\text { benar }\end{array}$ & $\begin{array}{l}\text { Berani } \\
\text { mencoba dan } \\
\text { tidak takut } \\
\text { gagal }\end{array}$ \\
\hline
\end{tabular}

\section{HASIL DAN PEMBAHASAN}

Collaborative Learning dilaksanakan dalam tiga tahap yaitu, awal, kegiatan inti dan penutup. Kegiatan awal pembelajaran adalah guru memberi salam, apersepsi dan memberi pertanyaan sedikit pada siswa sebagai pemanasan. Pada kegiatan inti, guru menugaskan siswa untuk membuat kelompok dan melaksanakan alur collaborative learning sesuai dengan tipe yang diterapkan. Penelitian ini menggunakan 3 tipe yaitu, learning together (sederhana), TGT (menengah) dan TAI (kompleks). Dari penerapan ketiga tipe tersebut peneliti mendapatkan hasil sebagai berikut. 


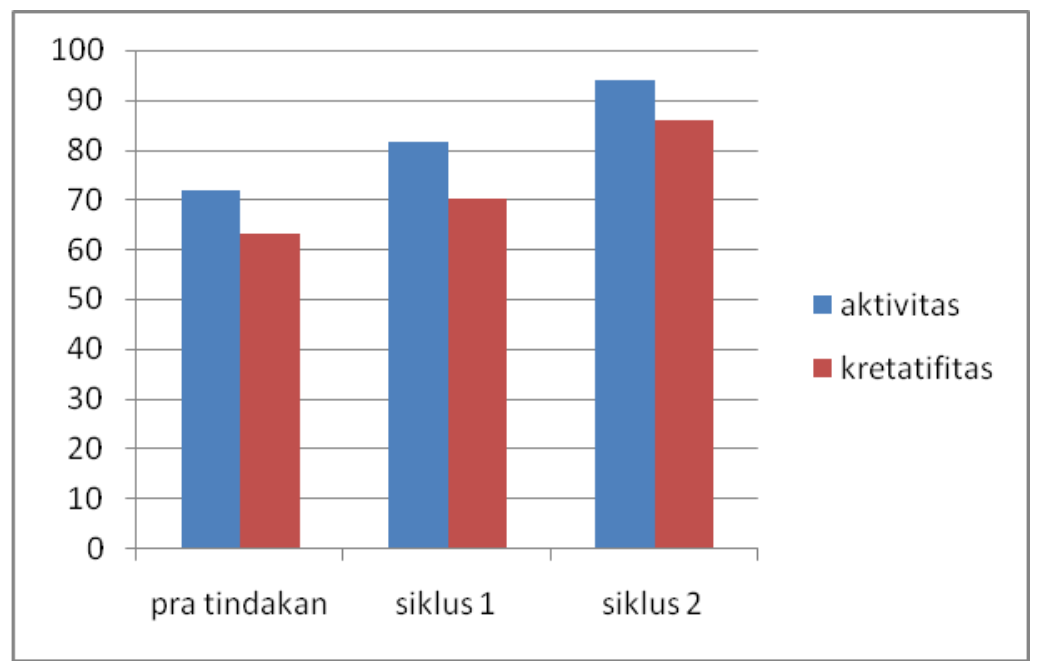

Gambar 1. Prosentase Aktivitas dan Kretifitas siswa

Grafik diatas menunjukkan bahwa terjadi peningkatan pada aktivitas dan kreatifitas siswa mulai dari tes pra-tindakan, siklus I dan siklus II. Terkait dengan aktifitas siswa, pada pratindakan berada pada kriteria sedang yaitu $71,8 \%$, tes siklus I dalam kriteria tinggi yaitu $81,6 \%$ dan tes siklus II dalam kriteria sangat tinggi yaitu 94\%. Dari siklus I ke siklus II, aktivitas siswa meningkat $13,6 \%$.

Hal tersebut mengindikasikan bahwa kreatifitas siswa mengalami peningkatan. Pada tes pra-tindakan, kretifitas siswa berada dalam kriteria rendah yaitu 63\%, siklus I dalam kriteria sedang yaitu $70 \%$ dan tes siklus II dalam kriteria tinggi yaitu $86 \%$. Dari siklus I ke siklus II, aktivitas siswa meningkat 16\%.Dapat disimpulkan bahwa setelah siklus 2 mayoritas siswa sudah masuk dalam indikator sangat kreatif.

Persentasi diatas masih bersifat global, belum memperlihatkan bagaimana peningkatan aktivitas dan kreatifitas secara rinci. Berikut ini adalah tabel peningkatan aktivitas siswa per indikator. 
Tabel 3. Peningkatan Aktivitas dan Kreatifitas Siswa Tiap Indikator

\begin{tabular}{|c|l|c|c|c|}
\hline \multirow{2}{*}{ No. } & \multicolumn{1}{|c|}{ Indikator } & $\begin{array}{c}\text { Pra } \\
\text { Tindakan }\end{array}$ & $\begin{array}{c}\text { Siklus I } \\
\text { Rata - } \\
\text { Rata }\end{array}$ & $\begin{array}{c}\text { Siklus 2 } \\
\text { Rata }- \\
\text { Rata }\end{array}$ \\
\hline & Rata - Rata & & \\
\hline 1 & Memperhatikan apa yang disampaikan guru & 3.5 & 3.8 & 3.9 \\
\hline 2 & Berani perform dan menyampaikan pendapat & 3.1 & 3.5 & 3.9 \\
\hline 3 & Berani bertanya saat menghadapi kesulitan & 3 & 3.6 & 4 \\
\hline 4 & $\begin{array}{l}\text { Bertanggung jawab terhadap tugas masing } \\
\text { masing }\end{array}$ & 2.8 & 3.5 & 3.9 \\
\hline 5 & Mencari referensi lain selain buku & 2.2 & 2.6 & 3.4 \\
\hline 6 & Semangat belajar & 3 & 3.5 & 3.8 \\
\hline 7 & Menyelesaikan tugas mandiri & 2.5 & 2.6 & 3.3 \\
\hline 8 & Menanggapi pendapat teman & 2.7 & 3.1 & 3.9 \\
\hline & \multicolumn{1}{|c|}{} & & \\
\hline & Kreatifitas Siswa & 2.7 & 2.3 & 3.6 \\
\hline 1 & Kelancaran Berpikir & 2.6 & 2.8 & 3.7 \\
\hline 2 & Berpikir Luwes & 2.3 & 2.8 & 3.1 \\
\hline 3 & Berpikir Original & 2.2 & 2.5 & 3.1 \\
\hline 4 & Bersifat Imajinatif & 2.8 & 3.2 & 3.7 \\
\hline 5 & Rasa Ingin Tahu & 2.7 & 3.3 & 3.5 \\
\hline 6 & Berani Mengambil Resiko & & & \\
\hline
\end{tabular}

Paparan kreatifitas siswa per aspek dijabarkan dalam paparan data berikut ini:

(a) Kelancaran

Indikator dari aspek kelancaran adalah siswa menghasilkan banyak ide atau gagasan saat menanggapi pertanyaan dari guru maupun kelompok lain. Banyaknya ide siswa pada tes pra-tindakan masih standar yaitu 2,7 atau 0,3 mendekati indikator kreatif. Masih ada siswa yang hanya bermain HP dan berbicara dengan temannya ketika guru memberikan instruksi sehingga ketika ditanya guru, siswa hanya menjawab seadanya. Pada tes siklus I siswa masih merasa jenuh karena mereka yang tidak terbiasa berpikir sendiri ditugaskan untuk menggali informasi sendiri sehingga nilai rata-rata siswa turun menjadi 2,3. Berbeda dengan siklus II, hanya beberapa siswa yang adu argumen. Hasil tersebut bukan berarti siswa menurun daya kreatifitasnya namun siswa lebih menggali kreatifitasnya dengan menjawab pertanyaan 
kelompok lain disertai alasan yang jelas sehingga tidak ada jawaban yang perlu ditanggapi oleh siswa lain. Pada siklus 2 nilai rata-rata meningkat tajam menjadi 3,6.

(b) Keluwesan

Indikator dari aspek keluwesan adalah mengemukakan strategi- strategi yang beragam (keragaman ide) pada saat mengerjakan tugas kelompok. Pada tes pra-tindakan sulit ditemukan keragaman ide yang dikemukakan oleh siswa. Siswa cenderung meminta bantuan temannya pada saat ditanya oleh guru. Bahkan ketika pertanyaan tersebut dilempar ke siswa lainnya, siswa hanya menjawab "sama". Hal tersebut membuat nilai rata-rata siswa menjadi 2,6 atau 0,4 dibawah nilai kreatif. Pada siklus I siswa mulai mengemukakan ide mereka baik dalam kerja kelompok maupun saat ditanya oleh guru.Tak jarang siswa menjawab pertanyaan guru dengan ilustrasi.

Siswa mulai menunjukkan keluwesan berpikir dan meningkatkan nilai rata-rata aspek keluwesan menjadi 2,8. Pada siklus II siswa memiliki tingkat pemahaman yang tinggi terhadap materi yang disampaikan guru sehingga jawaban siswa lebih beragam. Meskipun inti jawabannya sama namun cara penyampaianya berbeda. Pada siklus 2 nilai rata-rata aspek keluwesan menjadi 3,7 atau 0,4 dibawah nilai sempurna.

(c) Keaslian

Indikator aspek keaslian adalah siswa dapat memunculkan ide-ide yang asli dari logikanya sendiri bukan dari bisikan temanya. Pada pra tindakan nilai rata-rata aspek keaslian hanya 2,3, hal itu karena siswa masih belum punya gambaran pada saat menjawab pertanyaan. Pada siklus 1 pembelajaran dengan model collaborative learning siswa mulai mampu memunculkan ide yang diperkuat dengan alasan yang logis atau berdasarkan literatur lain yang tidak dimiliki temannya. Hal tersebut meningkatkan nilai rata- rata aspek keaslian menjadi 2,8. Pada siklus 2 keaslian pendapat siswa terihat ketika mereka menjawab pertanyaan maupun menanggapi pernyataan teman. Pada siklus 2 siswa bisa mempertahankan pendapatnya dengan ilustrasi. Ilustrasi yang diberikan adalah kejadian sehari-hari mereka. Pada siklus 2 nilai rata-rata aspek keaslian meningkat menjadi 3.1.

(d) Imajinatif

Imajinatif disini adalah kemampuan siswa melogika sebuah pertanyaan sehingga menemukan ilustrasi yang mampu meningkatkan pemahamannya sendiri. Pada tes pra 
tindakan, nilai rata-rata aspek ini adalah 2,2 karena siswa hanya termenung dan bingung dengan maksud dari guru namun setelah siklus 1 siswa sudah bisa membayangkan apa yang terjadi dengan akun ketika terjadi suatu transaksi sehingga meningkatkan rata-rata nilai aspek ini menjadi 2,5. Pada siklus 2 siswa dapat memahami maksud soal bahkan ada yang bisa menjelaskan secara runtut beserta alasan dengan ilustrasi yang mudah dipahami sehingga nilai rata-rata aspek ini meningkat lagi menjadi 3,1 .

(e) Rasa ingin tahu

Rasa ingin tahu siswa adalah aspek penting dari kreatifitas karena dengan keingintahuan mereka, guru dengan mudah memnyalurkan ilmu pada siswa. Pada tes pratindakan, rata-rata nilai siswa pada aspek ini adalah 2,8 karena siswa hanya gaduh dan tidak memperhatikan seakan acuh dengan pelajaran, meskipun ada beberapa siswa yang memang ingin mengerti akuntansi. Siklus 1 memberikan efek positif yaitu nilai rata-rata siswa meningkat menjadi 3,2. Pada fase ini siswa sudah mulai kondusif dan nyaman dalam belajar bahkan ada siswa yang cerewet (sering bertanya). Hal tersebut karena stimulasi dari guru yang selalu mengapresiasi siswa yang bertanya meskipun terkadang ada yang cuma cari perhatian. Pada siklus 2, rasa ingin tahu siswa lebih meningkat menjadi 3,7 karena siswa diberikan buku paket dari perpustakaan sehingga mereka lebih leluasa dalam menggali informasi. Siklus 2 menunjukan peningkatan yang significant karena siswa lebih menguasai materi daripada siklus 1 .

(f) Berani mengambil resiko

Aspek ini dianggap penting dalam kreatifitas karena apapun pendapat siswa harus bisa dipertanggung jawabkan pada kelompoknya. Pada pra-tindakan, nilai rata-rata siswa pada aspek ini hanya 2,7 karena mayoritas siswa hanya berbisik pada teman sebelahnya ketika mempunyai gagasan dan tidak berani menjawab sendiri dengan alasan takut salah. Pada siklus 1 siswa diajarkan untuk berani menjawab meskipun salah. Guru selalu memotivasi untuk mencoba daripada hanya sebagai tokoh dibalik layar. Meskipun siswa salah, guru tetap memberi nilai pada aspek kreatifitas. Hal ini meningkatkan nilai rata-rata menjadi 3,3. Pada siklus 2, nilai rata-rata siswa kembali meningkat menjadi 3,5. Pada fase ini siswa sangat rileks untuk menjawab karena apapun jawabannya akan dihargai oleh guru. 
Paparan kreatifitas siswa per aspek dijabarkan dalam paparan data berikut ini:

1. Memperhatikan apa yang disampaikan guru

Pada pra tindakan, keadaan siswa sudah kondusif, siap menerima pelajaran dan tenang. Nilai rata-rata siswa sudah baik yaitu 3,5. Pada siklus 1 setiap observer mengawasi 6 siswa sehingga siswa lebih memperhatikan guru karena merasa diawasi namun setelah mereka nyaman pada pertemuan pertama, mereka lebih tenang pada pertemuan kedua sehingga suasana kelas lebih kondusif lagi. Nilai rata-rata pada siklus 1 meningkat menjadi 3,8. Pada siklus 2 siswa tak hanya menyimak apa yang dijelaskan guru namun mereka juga mengamati jawaban siswa lain agar ada celah untuk menanggapi sehingga nilai rata-rata siswa pada aspek ini meningkat menjadi 3,9.

2. Berani perform dan menyampaikan pendapat

Pada pra tindakan, nilai rata-rata siswa pada aspek ini adalah 3,1 karena mayoritas siswa mau menjawab pertanyaan guru, hanya beberapa siswa yang diam dan bicara sendiri. Pada siklus 1 siswa lebih berani menyampaikan pendapat walaupun salah namun tetap dipuji guru sehingga siswa merasa lebih nyaman saat menyampaikan pendapatnya dan meningkatkan nilai rata-rata siswa menjadi 3,5. Hasil yang significan terlihat pada siklus 2, yaitu ketika hamper seluruh siswa mampu menjawab pertanyaan guru maupun menanggapi jawaban siswa dengan alasan yang logis berdasarkan ilutrasi sehingga nilai rata-rata siswa pada aspek ini meningkat menjadi 3,9.

3. Berani bertanya saat meghadapi kesulitan

Proses KBM pra tindakan yang kondusif mempengaruhi siswa untuk mau bertanya karena siswa mengikuti arus siswa lainnya yang berorientasi tinggi untuk mendapatkan nilai. Pada pra tindakan, nilai rata-rata pada aspek ini adalah 3. Siklus 1 menuntut siswa untuk lebih aktif karena pada saat collaborative learning penilaian siswa diambil dari nilai individu dan kelompok. Hal itu yang mendorong siswa bertanya pada guru maupun teman sekelompoknya ketika ada kesulitan. Pada siklus 1 nilai rata-rata siswa meningkat signifikan menjadi 3,5. Pada siklus 2 aspek ini sangat terlihat karena siswa diberikan buku paket sehingga mereka lebih mudah mencari informasi dan lebih mudah membuat pertanyaan. Nilai yang dihasilkan pada siklus 2 adalah 4 . 
4. Bertanggung jawab terhadap tugas masing - masing

Pada pra tindakan, nilai rata-rata aspek ini hanya 2,8 karena masih belum ada tugas sehingga indikator ini belum terlihat. Pada siklus 1 indikator ini bisa dilihat pada saat guru memberi PR pada buku LKS mereka. Esok hari ketika ditanya, mereka sudah mengerjakan semua. Hal itu menunjukkan bahwa siswa bertanggung jawab pada tugas masing-masing meskipun salah namun tetap mereka kerjakan sehingga meningkatkan nilai rata-rata pada aspek ini menjadi 3,5. Pada siklus 2, indikator ini terlihat pada saat pertemuan pertama, mendapat tugas yang banyak dengan waktu sedikit membuat mereka harus membagi tugas meskipun notulenya tetap 1. Pembagian tugas membuat pekerjaan selesai tepat waktu. Nilai yang dihasilkan pada siklus 2 termasuk dalam kategori sangat aktif yaitu 3,9.

5. Mencari referensi lain selain buku

Pada pra tindakan, aspek ini hampir tidak ada karena belum ada tugas, sehingga nilai ratarata siswa pada aspek ini hanya 2,2. Pada siklus 1 siswa dituntut untuk lebih aktif karena waktu yang singkat dengan jumlah soal yang banyak. Hal itu membuat siswa mencari referensi lain, misal internet atau catatan pribadi. Siswa merasa senang jika menemukan gagasan dari internet atau catatan pribadi karena itu bisa menambah nilai. Pada siklus 1, nilai rata-rata pada aspek ini meningkat menjadi 2,6. Pada siklus 2 buku paket yang dibagikan dapat menjadi referensi tambahan, namun siswa yang aktif tetap menggunakan internet ketika akan mengemukakan pendapatnya sehingga jawabanya sistematis. Hal ini membuat nilai rata-rata aspek ini meningkat menjadi 3,4.

6. Semangat belajar

Pada pra tindakan, nilai rata-rata siswa pada aspek ini adalah 3 karena mayoritas siswa sudah mulai semangat belajar meskipun ada yang acuh dalam proses KBM. Pada siklus 1 aspek ini terlihat ketika pada prtemuan kedua semua siswa mengumpulkan PR di depan kelas. Hal itu menunjukan bahwa siswa semangat belajar setelah mendapat treatment pada hari pertama sehingga nilai rata-rata siswa pada aspek ini meningkat menjadi 3,5. Pada siklus 2 aspek ini sangat terlihat ketika siswa diagikan buku paket. Suasana kelas menjadi hening ketika guru menjelaskan salah satu contoh soal di buku paket. Siswa sangat antusias dengan instruksi guru. Pada siiklus 2 nilai rata-rata siswa pada aspek ini meningkat menjadi 3,8 . 
7. Menyelesaikan tugas mandiri

Nilai 2,5 yang ada pada pra tindakan ini muncul karena masih belum ada tugas dari guru saat pra tindakan. Pada siklus 1 indikator ini bisa dilihat pada saat guru memberi PR pada buku LKS mereka. Esok hari ketika ditanya, mereka sudah mengerjakan semua. Hal itu meningkatkan nilai rata-rata siswa pada aspek ini menjadi 2,6. Pada siklus 2 indikator ini terlihat pada saat pertemuan pertama, mendapat tugas yang banyak dengan waktu sedikit membuat mereka harus membagi tugas meskipun notulennya tetap 1. Pembagian tugas membuat pekerjaan selesai tepat waktu. Tugas yang diterima dikerjakan pada kertas lain dan digabungkan dalam LKS. Nilai rata-rata siswa meningkat tajam pada siklus 2 yaitu 3,3.

8. Menanggapi pendapat teman

Pra tindakan nilai rata-rata siswa pada aspek ini hanya 2,7 karena siswa masih pasif dalam menanggapi pendapat teman. Siswa tidak mau menanggapi pendapat teman jika tidak ditunjuk guru. Pada siklus 1 siswa dilatih untuk berani menyampaikan pendapat walaupun salah sehingga siswa merasa lebih nyaman saat menyampaikan pendapatnya. Siswa yang menanggapi pendapat siswa lain dibimbing oleh guru agar percaya diri saat bicara. Guru memberikan sedikit clue ketika siswa merasa bingung dengan jawaban sendiri. Pada siklus 1 nilai rata-rata pada aspek ini meningkat menjadi 3,1. Pada siklus 2, mayoritas siswa mampu menanggapi jawaban siswa dengan alasan yang logis berdasarkan ilustrasi sehingga nilai rata-rata siswa meningkat tajam menjadi 3,9.

Hasil diatas menggambarkan hal seperti yang dikemukakan oleh Sanjaya (2008) yang menyatakan bahwa konstruktivistik adalah proses membangun atau menyusun pengetahuan baru dalam struktur kognitif siswa berdasarkan pengalaman. Yang dibuktikan dari jawaban siswa dengan alasan yang tepat seperti berikut ini:

Guru : : Modal? Apa ada yang mau menambahkan?

Siswa B : : iya pak benar modal karena modal adalah akun passive. Jika akun passiva bertambah, maka berada di sebelah kredit.

Collaborative learning membuat siswa menemukan pengetahuan, konsep dan bisa membuat kesimpulan tentang apa yang baru saja dikerjakan bukan sekedar mengumpulkan 
informasi saja. Hasil diatas sesuai dengan teori yang dikemukakan Aunurahman (2009) bahwa konstruktivistik memberikan arah yang jelas bahwa kegiatan belajar merupakan kegiatan aktif dalam upaya menemukan pengetahuan, konsep, kesimpulan, bukan sekedar merupakan kegiatan mekanistik untuk mengumpulkan informasi atau fakta saja. Hal ini dibuktikan pada percakapan berikut ini:

Siswa $F \quad$ : Dibeli secara tunai seperangkat komputer senilai Rp 4.000 .000 untuk memudahkan pencatatan.

Jawabannya ..... hmmm........ .

Siswa $\quad$ : Saya saja pak $\ldots$

Guru $\quad$ Iya silahkan...

Siswa E $\quad$ : Jawabannya adalah komputer bertambah Rp 4.000 .000 dan kas berkurang Rp.4.000.000.

Guru ada jawaban lain?

Siswa $F \quad$ : Saya pak... Karena komputer termasuk peralatan maka jurnalnya adalah Peralatan bertambah dan kas berkurang.

Guru : Iya benar. Pertanyaanya kenapa Komputer termasuk peralatan?

Siswa $G \quad$ : Saya saja pak. Karena komputer adalah benda yang tidak akan dijual sebelum masa pakainya habis namun seiring berjalanya waktu, harga komputer akan menyusut.

Jawaban siswa $\mathrm{G}$ menunjukkan siswa telah menemukan pengetahuan dan konsep yang dapat dibuat sebagai sebuah simpulan dengan bahasa mereka sendiri.

\section{SIMPULAN}

Berdasarkan hasil penelitian dapat disimpulkan bahwa dengan menerapkan pembelajaran model collaborative learning, skor aktivitas dan kreatifitas siswa dari tes pertama yaitu pratindakan kelas siklus I kemudian ke siklus II mengalami peningkatan.

1. Skor kreatifitas siswa meningkat $10 \%$ dari tes pra-tindakan ke siklus I dan meningkat lagi $15 \%$ pada siklus II.

2. Pembelajaran akuntansi dengan model collaborative learning berjalan dengan baik dan 
dapat meningkatkan aktivitas dan kreatifitas siswa. Pelaksanaan pembelajaran dengan model ini pada siklus II lebih baik daripada siklus I. Kekurangan pada siklus I telah diperbaiki pada siklus II, yaitu alokasi waktu siswa dalam mengerjakan tugas di siklus II ditambah dengan melaksankaan penyampaian materi menggunakan bantuan buku paket sehingga dapat mengurangi alokasi waktu siswa dalam mencatat sehingga waktu yang digunakan siswa untuk latihan bertambah. Tahapan dalam metode ini meliputi : (a) penyampaian materi, (b) siswa latihan soal sesuai dengan materi, (c) siswa diberi kesempatan menyelesaikan pertanyaan dari guru.

\section{SARAN}

Berdasarkan kesimpulan penelitian ini, diajukan beberapa saran sebagai berikut:

1. Aktivitas dan kreatifitas siswa perlu ditingkatkan dalam pembelajaran akuntansi, upaya peningkatan ini dapat menggunakan model collaborative learning atau model pembelajaran yang lainya.

2. Diharapkan dalam pembelajaran akuntansi guru lebih memberi kesempatan dan ruang untuk siswa dalam menyampaikan pendapat atau bertanya sehingga aktivitas dan kreatifitas siswa lebih berkembang.

\section{DAFTAR RUJUKAN}

Ari,S. 2014. Pembelajaran Aktif (Active Learning). Online http://eng.unri. c.id/download/teaching-improvement/BK2_Teach Learn_2/Active\%20learning_5.doc. pada 11 november 2014

Aunurrahman. 2009. Belajar dan Pembelajaran. Bandung: Alfa Beta.

Bennett, C., Howe, C., Truswell, E. 2002. Small Group Teaching and Learning in Psychology. Ltsn Psychology.Online http://riszkyramadhan85.wordpress.com/2011/05/17/1/. Pada 9 november 2014

Hamalik, Oemar. 2001. Proses Belajar Mengajar. Jakarta: Bumi Aksara Sardiman. 2007. Interaksi Belajar Mengajar. Jakarta: Raja Grafindo

Hamdani, A. 2002. Pengembangan Kreativitas, Jakarta : Pustaka As-Syifa 
Munandar, Utami, 2004. Pengembangan Kreativitas Anak Berbakat,Jakarta : Asdi Mahasatya

Sanjaya, Wina. 2008. Strategi Pembelajaran Berorientasi Standar Proses Pendidikan. Jakarta: Prenada Media Group.

Susanto, Ahmad, 2011. Perkembangan Anak Usia Dini, Jakarta : Kencana.

Vigotsky, Piaget. 1989. Constructivism. Online.http://magister-pendidikan.blogspot.com/p/teorikonstruktivistik.html. Pada 20 november 2014 